\title{
KONTRIBUSI HAKIM PEREMPUAN DALAM PENEGAKAN HUKUM DI INDONESIA
}

\author{
Djazimah Muqoddas \\ Mahkamah Agung Republik Indonesia \\ Email: djazimahmuqoddas@yahoo.com
}

\begin{abstract}
This article describes the contribution of female judges in law enforcement in Indonesia through the approach of a critical study of the Koran interpretation letter al-Nisâ' verse 34 and an explanation of the hadiths of the Prophet Muhammad SAW who describes the position of women as judges in the judiciary. So this article will be focused on: (1) polemic female judges in religious courts; (2) female judges in the legal system in Indonesia; and (3) the position of women judges in Islamic legal system. From this discussion, the female judge is required to give good imaging as judges always give a good example to the parties and to other law enforcement officials, as long as he completed cases in the judicial sphere. However, imaging judge women as law enforcement officials so bound by a code of conduct (ethical code) and the oath of their profession.
\end{abstract}

\begin{abstract}
Abstrak
Tulisan ini akan menjelaskan kontribusi hakim perempuan dalam penegakan hukum di Indonesia melalui pendekatan studi kritis atas tafsir al-Quran surat al-Nisâ' ayat 34 dan penjelasan tentang hadits-hadits Nabi SAW yang menjelaskan tentang kedudukan perempuan sebagai hakim. Sehingga tulisan ini akan memfokuskan kepada pembahasan mengenai: (1) polemik hakim perempuan di Pengadilan Agama; (2) hakim perempuan dalam sistem hukum di Indonesia; dan (3) kedudukan hakim perempuan dalam sistem hukum Islam. Dari pembahasan ini, maka hakim perempuan dituntut untuk memberikan pencitraan yang baik sebagai hakim yang selalu memberikan contoh baik kepada para pihak dan kepada aparatur penegak hukum lainnya, selama ia menyelesaikan perkara di dalam lingkup peradilan. Namun, pencitraan hakim perempuan sebagai aparatur penegak hukum sangat terikat dengan kode etik dan sumpah profesinya.
\end{abstract}

Kata Kunci:

Hakim Perempuan, Sistem Hukum, Pengadilan Agama

\section{A. Pendahuluan}

Peran hakim perempuan di Peradilan Agama ini memunculkan asumsi bahwa minimnya kuota hakim perempuan di Peradilan Agama dan lemahnya kesempatan untuk mengakses jabatan publik dilatarbelakangi oleh perdebatan seputar keabsahan hakim perempuan meskipun ia telah diatur di dalam peraturan dan perundang-undangan. Implikasi dari asumsi telah berakibat kepada munculnya pandangan bias gender mengenai kesempatan perempuan untuk menduduki jabatan hakim.

Salah satu indikatornya adalah Peradilan
Agama kurang memberikan kesempatan bagi perempuan untuk berkiprah dan berkarir secara maksimal di lembaga yudikatif ini. Hal ini dapat dibuktikan dengan masih minimnya upaya pemberdayaan hakim perempuan pada lembaga-lembaga pemerintahan. Indikator lainnya juga tampak pada data www.badilag.net tahun 2009 yang menunjukkan diagram bahwa perempuan masih terbatas peluang dan kesempatannya untuk menjadi hakim. Data yang ada tampaknya menjadi patokan sementara yang membuktikan bahwa hakim perempuan yang berpendidikan S2 hanya $13 \%$ dan yang bergelar sarjana seba- 
nyak 19\%. Sedangkan pada tingat banding, hakim perempuan yang berpendidikan S2 sebanyak $6,3 \%$ dan sarjana $4,3 \%$.

Kemudian ditinjau dari segi yuridis keabsahan hakim perempuan terkait pula dengan sejarah peraturan dan perundang-undangan tentang kekuasaan kehakiman. Peluang bagi hakim perempuan di Peradilan Agama baru terbuka setelah dikeluarkannya UndangUndang Nomor 1 Tahun 1974 tentang Perkawinan dan Undang-Undang Nomor 7 Tahun 1989 Tentang Peradilan Agama. Pendek kata, sebelum keluar dua perundang-undangan tersebut, peluang perempuan untuk menjadi hakim tampaknya belum terakomodasi baik dari segi regulasi maupun kompetensinya.

Setelah keluarnya UUPA Nomor 3 Tahun 2006 jo. diamandemen dengan UUPA Nomor 50 Tahun 2009 kuantitas hakim perempuan mengalami peningkatan dibandingkan hakim laki-laki yang notabene jumlah hakim laki-laki sebelumnya sudah cukup banyak dibandingkan dengan hakim perempuan. Adapun fenomena yang untuk diangkat dalam tulisan ini adalah saat ini ada peluang yang sangat lebar bagi perempuan untuk berkiprah baik pada ranah lembaga yudikatif maupun lembaga lainnya, termasuk di dalamnya menjadi hakim di Pengadilan Agama.

\section{B. Polemik Hakim Perempuan di Penga- dilan Agama}

Dalam perspektif fiqh Islam klasik telah dirumuskan dan dibakukan bahwa kaum laki-laki sederajat lebih tinggi daripada perempuan dalam kepemimpinan di masyarakat. Namun demikian, yang menjadi persoalan krusial adalah perlunya melakukan reinterpretasi terhadap posisi dan citra perempuan dalam fiqh Islam. Dengan kata lain, rumusan figh yang lebih adil gender mestinya menjadi agenda yang merupakan bagian dari usaha menjadikan Islam sebagai rahmatan lil 'âlamîn. Tetapi, dengan catatan pula bahwa asumsi teologis yang terbangun sebelumnya (yang menjadi sumber rujukan mengenai pencitraan perempuan dan relasinya dengan laki-laki) hendaknya diluruskan agar tidak ada anggapan bahwa pencitraan perempuan dalam Islam telah menyalahi kehendak Allah.
Jika telaah secara mendalam, ada sejumlah argumen yang dijadikan dasar oleh kalangan fuqahâ' dalam melihat kedudukan hukum perempuan sebagai hakim, yakni:

Pertama, pemahaman tekstual terhadap ayat-ayat al-Quran yang secara subtansi telah memposisikan kaum laki-laki menjadi pemimpin bagi kaum perempuan. Kalangan fuqahâ' berpendapat demikian mengacu kepada QS. al-Nisâ' ayat 34 yang berbunyi:

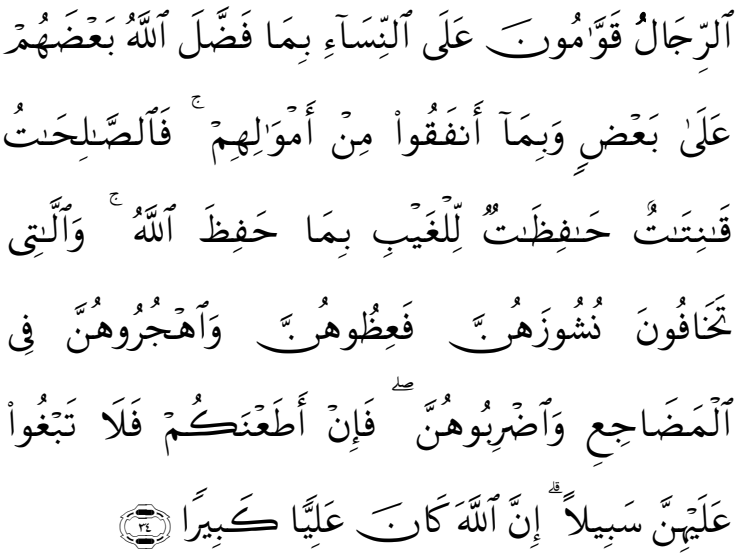

Kaum laki-laki itu adalah pemimpin bagi kaum wanita, oleh karena Allah telah melebihkan sebahagian mereka (lakilaki) atas sebahagian yang lain (wanita), dan karena mereka (laki-laki) telah menafkahkan sebagian dari harta mereka. Sebab itu, maka wanita yang saleh, ialah yang taat kepada Allah lagi memelihara diri ketika suaminya tidak ada, oleh karena Allah telah memelihara (mereka). wanita-wanita yang kamu khawatirkan nusyuznya, maka nasihatilah mereka dan pisahkanlah mereka di tempat tidur mereka, dan pukullah mereka. Kemudian jika mereka mentaatimu, maka janganlah kamu mencari-cari jalan untuk menyusahkannya. Sesungguhnya Allah Maha Tinggi lagi Maha besar.

Selain itu, kalangan fuqahâ' juga memandang bahwa hampir semua ayat yang ada dalam al-Quran yang mengatur masalah kepemimpinan cenderung berpihak kepada kaum laki-laki, misalnya dalam QS. al-Nisâ' ayat 59 yang berbunyi:

Analisis penulis terhadap tulisan Hussein Muhammad, Fiqh Perempuan (Yogyakarta: LkiS. 2001), hlm. 36-37. 


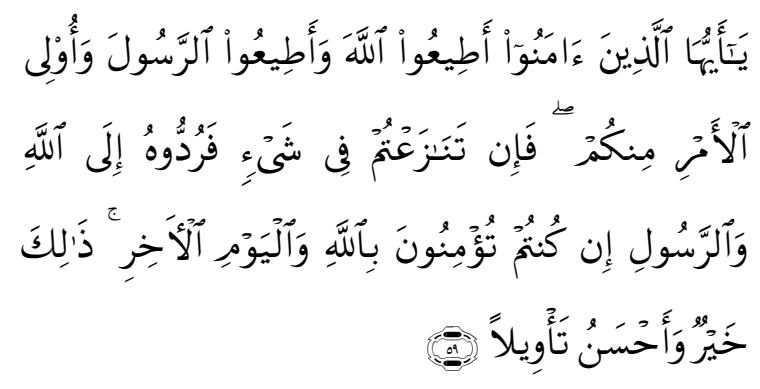

Hai orang-orang yang beriman, taatilah Allah dan taatilah Rasul-Nya, dan ulil amri di antara kamu. Kemudian jika kamu berlainan pendapat tentang sesuatu, maka kembalikanlah ia kepada Allah (al-Quran) dan Rasul (sunnahnya), jika kamu benar-benar beriman kepada Allah dan hari kemudian. yang demikian itu lebih utama (bagimu) dan lebih baik akibatnya.

Kedua, ada hadits shahih ahad yang dari segi substansi matan haditsnya melarang perempuan sebagai kepala negara yang diriwayatkan oleh Bukhârî, Ahmad, Tirmidzî, dan al-Nasâ'i dari Abû Bakrah r.a. Lebih lengkapnya dapat dilihat pada petikan hadits di bawah ini:

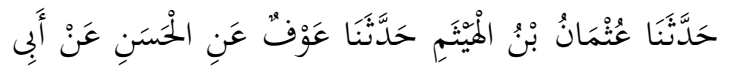

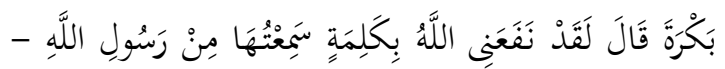

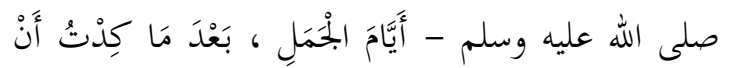

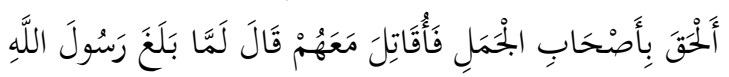

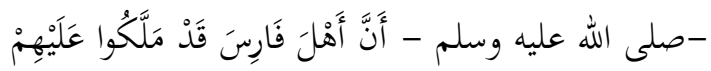

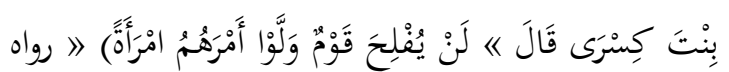

$$
\begin{aligned}
& \text { البخارى }
\end{aligned}
$$

Menceritakan kepada kami 'Utsmân bin al-Haitsam, menceritakan kepada kita 'Auf dari Hasan dari Abî Bakrah r.a., beliau berkata: Allah telah memberiku manfaat dengan kalimat yang aku dengar dari Rasulullah SAW pada hari perang Jamal setelah aku menganggap bahwa yang benar adalah pemilik unta ('Aisyah r.a.) sehingga aku berperang di

2 Muhammad bin 'Alî al-Syawkânî, Nayl alAuthâr (Beirut: Dâr al-Fikr. t.th.), juz. VIII, hlm. 263 dan al-Shan'ânî, Subul al-Salâm (Bandung: Maktabah Dahlan, t.th.), juz IV, hlm. 123. pihaknya. Kalimat yang aku dengar tersebut adalah ketika ada kabar yang sampai kepada Rasulullah SAW bahwa penduduk Persia telah mengangkat anak perempuan Kisra sebagai raja mereka maka Nabi SAW bersabda: "Tidak akan beruntung, suatu kaum yang menyerahkan kepemimpinan atas diri mereka kepada perempuan." (HR. Bukhârî)

Bunyi lafazh wallau amrahum dalam redaksi hadits tersebut diartikan mengangkat seseorang sebagai waliyy al-amrî (pemegang tampuk pemerintahan).

Ketiga, kondisi sosio-historis dan budaya pada masa sebelum dan awal datangnya Islam menunjukkan adanya suatu hegemoni budaya patriarki, yang mana kaum laki-laki diposisikan lebih tinggi daripada kaum perempuan. Sehingga peluang bagi perempuan untuk menjadi pemimpin lebih sempit ruangnya daripada kaum laki-laki. Meskipun dalam perjalanannya ditemukan pula fakta sejarah klasik yang mendukung adanya perempuan yang menjadi pemimpin, seperti: Ratu Saba, Ratu Bilqis, Ratu Cleopatra, dan Siti 'Aisyah (umm al-mu'minîn), serta sederet namanama pemimpin perempuan lain di zaman modern, seperti: Benazir Bhuto (Pakistan) dan Begum Khaleda Zhia (Bangladesh).

Mengacu kepada ketiga asumsi di atas, penting kiranya untuk menelaah bagaimana pandangan ulama fuqahâ' mengenai kedudukan hukum perempuan menjadi hakim. Kedudukan perempuan dalam pandangan ajaran Islam tampaknya tidak seperti diduga atau dipraktikkan dalam kenyataan di masyarakat. Ajaran Islam pada hakikatnya telah memberikan perhatian yang sangat besar dan memberikan kedudukan yang terhormat kepada kalangan perempuan. Misalnya, Muhammad al-Ghazâlî, ${ }^{3}$ salah seorang ulama besar, telah menulis:

Kalau kita mengembalikan pandangan ke masa sebelum seribu tahun, maka kita akan menemukan perempuan menikmati keistimewaan dalam bidang materi

3 Muhammad al-Gazâlî, al-Islâm al-Thâqah alMu'aththalah (Kairo: Dâr al-Kutûb al-Haditsah. 1964), hlm. 138. 
dan sosial yang tidak dikenal oleh perempuan-perempuan di kelima benua. Keadaan mereka ketika itu lebih baik dibandingkan dengan keadaan perempuan-perempuan Barat dewasa ini, asal saja kebebasan dalam berpakaian serta pergaulan tidak dijadikan bahan perbandingan.

Kemudian dipertegas oleh Mahmud Syalthut, ${ }^{4}$ syaikh pemimpin dari tertinggi lembaga-lembaga al-Azhar di Mesir telah menulis:

Tabiat kemanusiaan antara lelaki dan perempuan hampir dapat (dikatakan) sama. Allah telah menganugerahkan kepada perempuan sebagaimana menganugerahkan kepada lelaki. Kepada mereka berdua dianugerahkan Tuhan potensi dan kemampuan yang cukup untuk memikul tanggung jawab dan yang menjadikan kedua jenis kelamin ini dapat melaksanakan aktivitas-aktivitas yang bersifat umum maupun khusus. Karena itu, hukum-hukum syariat pun meletakkan keduanya dalam satu kerangka. Yang ini (laki-laki) menjual dan membeli, mengawinkan dan kawin, melanggar dan dihukum, menuntut dan menyaksikan, dan yang itu (perempuan) juga demikian, dapat menjual dan membeli, mengawinkan dan kawin, melanggar dan dihukum serta menuntut dan menyaksikan.

Sementara itu, kalangan ulama Imâm Mazhab yang bersikap menolak (kontra) menetapkan bahwa laki-laki sebagai syarat pemimpin. Oleh karena itu, perempuan tidak dibolehkan menjadi pemimpin politik dan hakim dalam pandangan jumhur ulama. Bahkan kalangan ulama mazhab seperti Imâm Syafi'i, Mâlik, dan Hanbali sepakat berpendapat bahwa perempuan tidak dibenarkan memimpin dengan analogi (qiyas) kepada larangan menjadi imam shalat. Substansi masalahnya adalah karena khawf al-fitnah, yaitu menjaga suasana yang mengganggu

4 Mahmod Syalthut, Min Tawjihat al-Islâm (Kairo: al-Idarat al-'Ammat al-Azhar. 1959), hlm. 193. atau menggoda hati dan pikiran laki-laki dalam beribadah. Sehingga termasuk pula dalam bidang politik pun perempuan diangap tidak dapat menjadi pemimpin dan bahkan menjadi hakim. ${ }^{5}$ Selain itu, pendapat senada yang menolak kedudukan perempuan sebagai pemimpin politik dan hakim juga dikemukakan oleh al-Mâwardî́ dan Abî Ya'lâ. ${ }^{7}$

Sedangkan kelompok ulama mendukung penerimaan perempuan diterima sebagai hakim dikemukakan oleh Imâm Abû Hanifah. la menegaskan bahwa perempuan dibolehkan menjadi hakim dalam perkara perdata (muamalah), tetapi tidak berlaku dalam perkara pidana (jinayah). Ditambahkan pula, ulama mazhab memandang hadits tentang larangan perempuan menjadi pemimpin mengindikasikan bahwa kapasitas Nabi saat menyampaikan hadits tersebut bukan dalam kapasitas sebagai Nabi dan Rasul yang mendukung kebenaran wahyu, tetapi harus dipahami dalam kapasitas Nabi sebagai manusia biasa (pribadi) yang mengungkap realitas sosial di masyarakat (bayân al-waqî), yakni mengantisipasi kemungkinan buruk yang terjadi di kemudian hari jika pemimpin diserahkan kepada perempuan. Pendek kata, penulis memandang pendapat hukum Imâm Hanafi, al-Syawkanî, dan Zamakhsarî yang memandang pemaksaan hadits yang berbentuk ikhbar (informatif atau berita) ke dalam masalah syariat, terutama dalam masalah kepemimpinan politik perempuan merupakan tindakan yang kurang bijaksana dan kurang kritis serta tidak proporsional. ${ }^{8}$

Adapun pandangan paling moderat dikemukakan pula oleh ulama lainnya seperti Taqiy al-Dîn al-Nabhânî, Muhammad 'Abduh, Nasr Hâmid Abû Zayd, Muhammad Hussayn

\footnotetext{
5 Hussein Muhammad, Figh Perempuan. Yogyakarta: LkiS. 2001), hlm. 36-37.

6 Menurut al-Mâwardî, syarat-syarat menjadi pemimpin politik ada tujuh, yaitu: (1) adil, (2) berilmu yang memungkinnya mampu melakukan ijtihad, (3) sempurna panca indera (salamat al-hawas), (4) sempurna anggota badannya, (5) cerdik, (6) berani, (7) berasal dari kaum Quraisy. Abû Hassan al-Mâwardî, alAhkâm al-Sulthâniyyah (Beirut: Dâr al-Fikr. t.th.), hlm. 6.

7 Ibid. hlm. 31.

8 Analisis penulis yang dikutip dari penjelasan Muhammad bin 'Alî al-Syawkânî, Nayl al-Authâr. hlm. 263 dan al-Shan'ânî, Subul al-Salâm (Bandung: Maktabah Dahlan. t.th.), juz IV, hIm. 123.
} 
'Abdullah dan M. Quraish Shihab. Keempatnya tampaknya sepakat bahwa akar permasalahan larangan perempuan menjadi pemimpin politik atau hakim tampaknya lebih banyak disandarkan kepada teks-teks wahyu yang ditafsirkan secara verbal dan normatif, tanpa mengkaji makna hukum dibalik teksteks wahyu tersebut. Misalnya, kata "al-rijâl" dalam QS. al-Nisâ' ayat 34 hendaknya bukan dimaknai "laki-laki", melainkan "sifat kelakilakian". Jadi, pemaknaan teks-teks pada ayat hukum menjadi subyektif. Oleh karena itu, penulis berpendapat bahwa mengacu kepada kedudukan, hak dan wewenang, serta tugas dan fungsinya, meskipun terikat dengan syarat-syarat yang mengikat, perempuan tampaknya dibolehkan menjadi hakim dan pemimpin politik. ${ }^{9}$

Pada gilirannya dapat dirumuskan bahwa kalangan ulama fuqahâ' dan ulama modern terbagi menjadi tiga bagian dalam melihat kedudukan perempuan menjadi hakim dan pemimpin, yakni ada yang membolehkan, ada yang tidak membolehkan, dan ada pula yang moderat. Namun perbedaan pendapat ulama fuqahâ' dan ulama modern tersebut juga berpengaruh terhadap pendapat ulama-ulama berikutnya hingga zaman modern sekarang.

\section{Hakim Perempuan dalam Sistem Hu- kum Indonesia}

Indonesia adalah negara hukum yang memilih demokrasi sebagai sistem politiknya. Sebagai negara hukum, Indonesia menempatkan hukum sebagai "panglima". Hukum yang berkembang di Indonesia adalah hukum Positif, hukum Islam, dan hukum Adat. Disebabkan Indonesia mayoritas penduduknya beragama Islam, peran umat Islam sangat penting dalam menentukan arah hu-

9 Analisis penulis terhadap pendapat Taqiy alDîn al-Nabhânî, Muqaddimah al-Dustûr (Beirut: Dâr alFikr. t.th.), hlm. 255-257; Muhammad 'Abduh, Tafsîr alManâr (Kairo: Dâr al-Maktab al-Misriyyah, t.th.), Nasr Hamid Abû Zayd, Human Rights in Islam dalam Human Rights Quarterly (The Hague: Kluwer Law Unversity Press. 2000), hlm. 7-10, Muhammad Hussayn 'Abdullah, al-Wâdlih fî Ushûl al-Figh (Beirut: Dâr al-Fikr. t.th.), hlm. 209 dan M. Quraish Shihab, Wawasan al-Qur'an (Bandung: Mizan. 1996), hlm. 131-133. kum yang berlaku di Indonesia. Atas dasar itu, hukum Islam tampaknya telah memberikan sumbangan terhadap hukum positif. ${ }^{10}$

Di samping itu, Indonesia tercatat sebagai salah satu negara yang telah ikut meratifikasi International Covenant on Civil and Political Rights (ICCPR) melalui Undang-Undang Nomor 11 Tahun 2006 dan International Covenant on Economic, Social, and Cultural Rights (ICESCR), yakni dua kovenan pokok tentang hak-hak sipil politik dan sosial, ekonomi, dan budaya. Dalam kedua kovenan tersebut diakui kesetaraan perempuan dan laki-laki dalam mengakses hak-hak yang diakui di dalamnya. Hak-hak publik itu mencakup hak politik; hak untuk memilih dan dipilih, hak-hak untuk diangkat dalam jabatan terpenting, pengakuan dan perlakuan sama dalam hukum dan pelayanan umum lainnya, berhak mendapat rasa aman dan perlindungan terhadap kekerasan suku, agama, suku, atau ras.

Demikian pula dengan hak-hak sipil, kebebasan bergerak, berpindah tempat, merubah dan mempertahankan kewarganegaraan, kebebasan berkumpul dan berserikat, berfikir, mengungkapkan perasaan, berekspresi dan mengeluarkan pendapat, memperoleh informasi yang dibutuhkan, menggunakan bahasa bebas, bebas memilih pasangan hidup, berhak dalam pelayanan pendidikan yang sama. Tak terkecuali dalam hakhak ekonomi; perlakuan sama dalam pencarian penghidupan yang layak, bekerja dan memilih pekerjaan sesuai dengan potensi yang dimiliki, berhak memiliki kekayaan pribadi dan kelompok secara tidak melanggar hukum. Hak-hak sosial dan budaya; kesempatan dan perlakuan sama dalam pelayanan umum dan kebebasan mengekspresikan budayanya. ${ }^{11}$

10 Wahiduddin Adams dalam disertasinya yang berjudul "Pola Penyerapan Fatwa Majelis Ulama Indonesia MUI dalam Peraturan Perundang-undangan 1975 - 1997", menjelaskan adanya sumbangan hukum Islam terhadap hukum positif.

11 M. Indradi Kusuma dan Wahyu Effendi, Kewarganegaraan Indonesia: Catatan Kritis Atas Hak Asasi Manusia dan Institusionalisasi Diskriminasi Warga Negara (Jakarta: FKKB dan GANDI. 2002), belum diterbitkan. 
Lebih dari itu, Undang-Undang Dasar 1945 telah secara nyata mengakui kesetaraan laki-laki dan perempuan. Selain itu, Indonesia telah memiliki Undang-Undang Nomor 39 Tahun 1999 tentang Hak Asasi Manusia dan Indonesia telah meratifikasi Konvensi Anti Diskriminasi terhadap Perempuan (CEDAW). Perlakuan terhadap warga negara yang tidak sesuai dengan peraturan dan ketentuan-ketentuan di atas dianggap melanggar hukum dan tidak mencerminkan semangat kesetaraan dan hak asasi manusia. Dalam Undang-undang Dasar 1945 secara detail dinyatakan kesetaraan tersebut dalam Pasal 27 ayat (1) dan (2), Pasal 28, Pasal 30, dan Pasal 31.

Ketentuan-ketentuan dalam pasal-pasal di atas menegaskan bahwa tidak adanya diskriminasi berdasarkan jenis kelamin. Baik laki-laki maupun perempuan dapat mengakses semua fasilitas yang dimiliki oleh republik ini. Perempuan dapat menjadi presiden dan ini pernah terjadi di Indonesia. Perempuan juga dapat menjadi hakim untuk semua perkara. Pada pasal 13 UU Nomor 3 Tahun 2006 tentang Perubahan atas Undang-Undang Nomor 7 Tahun 1989 tentang Peradilan Agama, menyebutkan syarat-syarat menjadi hakim yang berlaku bagi semua orang, yaitu:

1. Warga negara Indonesia;

2. Beragama Islam;

3. Bertakwa kepada Tuhan Yang Maha Esa;

4. Setia kepada Pancasila dan UndangUndang Dasar 1945;

5. Sarjana Syariah dan/atau Sarjana Hukum yang menguasai hukum Islam;

6. Sehat jasmani dan rohani;

7. Berwibawa, jujur, adil, dan berkelakukan tidak tercela;

8. Bukan bekas anggota organisasi terlarang Partai Komunis Indonesia termasuk organisasi massanya, atau bukan orang yang terlibat langsung dalam Gerakan 30 September/Partai Komunis Indonesia. ${ }^{12}$

Jelaslah bahwa Indonesia memberikan peluang yang sama bagi laki-laki dan perem-

12 Direktorat Jenderal Badan Peradilan Agama, Undang-undang Nomor 3 Tahun 2006 tentang Perubahan atas Undang-Undang Nomor 7 Tahun 1989 tentang Peradilan Agama (Jakarta: Badilag. 2006), hlm. 5-6. puan untuk menjadi hakim. Namun demikian, kendala-kendala bagi perempuan masih tetap ada. Persepsi yang membatasi hak-hak politik perempuan tidak terlepas dari pengaruh sistem dan nilai serta norma, steriotype politik serta wacana yang ada di lingkungan budaya sekitar, baik keluarga (suami, orang tua, mertua, anak, dan lain-lain), teman sekerja ataupun masyarakat pada umumnya. Terlebih lagi stigma ini ditopang dengan penjelasan/interpretasi atas nama "agama" yang bertendensi bias gender. ${ }^{13}$

Mengubah cara pandang dan pola pikir (mind set) masyarakat yang telah mendarah daging dan terpola pengkondisiannya pada benak pikirannya tidaklah mudah, memerlukan kerja keras yang tentunya harus dimulai dari penyadaran diri sendiri. Persoalannya adalah tidak banyak kaum perempuan berminat atau tertarik pada dunia politik; diawali dari pola penempatan yang telah dikotak-kotakkan dan stereotype, perempuan tepat dan pantasnya ada di ranah domestik, sebaliknya laki-laki ada di ranah publik. Belum lagi dunia politik diasumsikan sebagai dunia maskulin (keras, kasar, rasional, kompetitif, menakutkan) sehingga pantasnya hanya dimiliki laki-laki. Sementara ranah domestik berwatak feminim, lemah, lembut, emosional, ngalah, nurut (bahasa Jawa), halus, ramah; inilah fungsi dan tugas yang tepat dan cocok bagi perempuan; diam di rumah mengurus dan membereskan segala permasalahan di rumah tangga.

Sebuah buku yamg berjudul: "Amerika Menolak Presiden Perempuan"14 cukup mengagetkan. Negara yang dikenal sebagai negara demokrasi seperti Amerika, justru masyarakatnya memangkas hak perempuan untuk memegang kekuasan tertinggi. Alasan yang dikemukakan adalah di sana sedang mengalami konversi dan kembali pada semangat keagamaan. Dari awal revolusi Amerika (1775-2006) sampai sekarang yaitu kurang lebih 231 tahun, negara ini belum pernah memiliki presiden perempuan. Meski telah ba-

13 Zaitunah Subhan, Menggagas Figh Pemberdayaan Perempuan (Jakarta; el-Kahfi. 2008), hlm. 114.

14 Ahmad Mansur Suryanegara, Amerika Menolak Presiden Perempuan (Jakarta: Darul Falah. 1999), hlm. 93. 
nyak di abad ini pandangan-pandangan yang menolak adanya sex different leaders (pemimpin yang didasarkan pada perbedaan jenis kelamin).

\section{Politik Perempuan di Indonesia}

Kitab al-Quran secara tegas memberikan kesaksian dengan pengabadian namanya, Ratu Bilqis adalah sosok perempuan yang mampu memimpin negeri Saba' dengan sejumlah kekayaan yang melimpah ruah, sehingga dinyatakan oleh firman Tuhan sebagai pemimpin yang memiliki kekuasaan yang dahsyat. ${ }^{15}$ Bahkan perbincangan mengenai hak-hak politik perempuan dalam wacana Islam ${ }^{16}$ menimbulkan dua pemikiran besar, yaitu pemikiran politik perempuan dan sebaliknya yang mengakui bahwa Islam memberikan hak-haknya termasuk hak politik sama sebagaimana diberikan kepada laki-laki. Dalam penelaahan penulis sesungguhnya bukan teks ayat-ayat al-Quran yang membatasi kaum perempuan, namun penafsiran atas nash tersebut yang menyebabkan munculnya pemahaman yang membatasi hak-hak perempuan.

Berkenaan dengan hal tersebut, $M$. Quraish Shihab berpendapat bahwa perempuan memiliki hak-hak politik yang sama dengan laki-laki. Menurutnya, tidak ditemukan satu ketentuan agamapun yang secara tegas dapat dipahami sebagai melarang keterlibatan perempuan dalam bidang politik, atau membatasi bidang tersebut hanya untuk laki-laki. Dalih yang melarang keterlibatan perempuan dalam bidang politik dan publik kesemuanya dapat dilemahkan. ${ }^{17}$ Begitu juga dengan Hussein Muhammad yang berpendapat larangan perempuan menjadi pemimpin dalam hadis hanya bersifat informatif bukan mengikat. ${ }^{18}$

15 QS. al-Naml: 23-35.

16 Zaitunah Subhan, Perempuan dan Politik dalam Islam (Yogyakarta: Pustaka Pesantren \& El-Kahfi. 2004), hlm. 37.

17 M. Quraish Shihab, Membongkar Hadis-hadis Bias Jender. hlm. 27.

18 Hussein Muhammad, Membongkar Konsepsi Fiqih tentang Perempuan, dalam Syafiq Hasyim (ed.), Kepemimpinan Perempuan dalam Islam (Jakarta: $\mathrm{P}_{3} \mathrm{M}$.
Ketika perempuan memasuki dunia politik praktis hendaknya memiliki wewenang dan kewajiban untuk mengambil keputusan yang bisa mempengaruhi kehidupan yang melingkupi dimensi kehidupan bermasyarakat. Pengambilan keputusan dapat dilihat dari berbagai aspek, hendaknya mempunyai tataran ide yang memandang ke depan, dan pro aktif menyelesaikan permasalahan realitas kehidupan. Oleh karena itu peran perempuan di era global ini sangat diperlukan untuk mampu merubah paradigma pembangunan yang bisa mendorong upaya perubahan-perubahan sosial ke arah yang lebih baik dan bermanfaat.

Pada fase awal gerakan perjuangan kemerdekaan di Indonesia, kaum perempuan banyak ikut dalam gerakan kebangkitan kebangsaan dan perjuangan membela kemerdekaan. Bahkan perempuan pada fase ini telah memiliki suatu kesadaran untuk berpolitik dan mempunyai keberanian yang patut dibanggakan. Sudah barang tentu, tidak bisa diingkari adanya para pelopor perempuan hampir ada di setiap negeri ini. Nama-nama yang tidak asing lagi bagi bangsa Indonesia, seperti: R.A. Kartini, Dewi Sartika, Nyai Ahmad Dahlan, Rohana Kudus, Maria Walanda, Rasuna Said, Cut Nya' Dien, dan masih banyak nama lainnya, yang merupakan tokoh perempuan dari kalangan elit modern. Dengan keberanian dan ilmu pengetahuan mereka berupaya untuk menyadarkan kepada kaumnya tentang kedudukan dan peran perempuan dalam masyarakat.

Pada masa kolonial Hindia Belanda, kaum perempuan sudah berani mengambil keputusan-keputusan politik. Pada Konggres Perempuan Indonesia pertama yang diadakan di Yogyakarta, tanggal 22-25 Desember 1928, ada usaha memperjuangkan anggaran dana bagi para janda dan, memperbanyak pendidikan bagi kaum perempuan, serta mencegah perkawinan dini. Demikian pula ketika pada Konggres Kedua, tahun 1935, ada usaha memperjuangkan keadaan kaum buruh perempuan dan pada Konggres ketiga membahas tentang kedudukan dan peran perempuan serta usaha perbaikan nasib kaum perempuan.

t.th.), hlm. 45 . 
Pada Konggres pertama itulah dijadikan hari ibu yang diprakarsai oleh sejumlah organisasi perempuan (kini tidak kurang dari 70 organisasi perempuan yang bergabung) yang dikenal dengan nama KOWANI (Korps Wanita Indonesia); di tingkat satu dikenal dengan nama BKOW (Badan Koordinasi Organisasi Wanita) dan di tingkat dua GOW (Gabungan Organisasi Wanita). ${ }^{19}$

\section{Perempuan sebagai Mitra dalam Kebi- jakan Publik}

Dalam kancah politik, kebijakan publik merupakan salah satu bentuk pengambilan keputusan strategis. Kebijakan publik, menjadi sebuah keputusan berdasar aspirasi dan kebutuhan serta kepentingan masyarakat (yang terdiri dari laki-laki dan perempuan). Di negara kita ini sudahkah menampung hal-hal yang terkait dengan aspirasi kebutuhan dan kepentingan perempuan? Memang diakui tidaklah mudah untuk mengubah kebijakan politik maskulin yang selama ini telah mengakar, untuk itu dibutuhkan penyadaran yang utuh dalam proses pendewasaan pemahaman dari semua lapisan masyarakat dan bangsa.

Ada beberapa hal yang patut kita syukuri; telah ada political will, meski baru dalam bentuk Instruksi Presiden (Inpres) Nomor 9 Tahun 2000 tentang PUG (Pengarus Utamaan Gender) yang sering juga disebut dengan meanstreming gender. Konsekuensinya bahwa seluruh aparat, departemen, nondepartemen, angkatan, dan NGO hendaknya melaksanakannya. PUG merupakan sebuah strategi untuk mendapat KKG (Kesetaraan dan Keadilan Gender) bukan hanya KKG merupakan visi dari Kementerian Pemberdayaan Perempuan RI. Akan tetapi, KKG sudah disepakati dalam RPJMN (Rencana Pembangunan Jangka Menengah Nasional) di bawah kepemimpinan Presiden Susilo Bambang Yudhoyono dan Wakil Presiden Muhammad Jusuf Kalla, sebagai strategi pembangunan bangsa dan negara Indonesia. Hal ini menjadi sangat penting agar kepentingan, kebutuhan dan aspirasi perempuan bisa terakomodir. Sebab populasi perempu-

19 Zaitunah Subhan, Menggagas Fiqh Pemberdayaan Perempuan. hlm. 113. an di negara ini separuh dari penduduk secara keseluruhan, perempuan sebagai mitra laki-laki juga sebagai subjek pembangunan bangsa dan negara ini.

Demikian juga kebijakan publik yang terkait dengan berbagai pihak, perempuan sebagai mitra laki-laki tidak bisa begitu saja diabaikan, tetapi harus dan mesti terlibat. Terbentuknya good governance adalah keterlibatan tiga domain yang tak terpisahkan, satu dengan yang lain saling terkait, yaitu: pemerintah (ekskutif, legislatif, yudikatif), dunia usaha (peluang-peluang sektor ekonomi, perlindungan kerja, pajak dan sebagainya harus ada keberpihakan tidak hanya pada satu kelompok tertentu), demi pembangunan kesejahteraan masyarakat; dan media massa (agar opini publik yang menyuarakan KKG dapat tercapai).

Di era globalisasi berbarengan dengan kebijakan pemerintah tentang ekonomi daerah, sebenarnya menjadi peluang besar bagi kaum perempuan untuk ikut berpartisipasi aktif bersama mitranya (laki-laki) dalam menentukan arah kebijakan. Sudahkah kebijakan otonomi daerah dirasakan manfaatnya oleh perempuan ataukah sebaliknya justru perempuan banyak dirugikan? Apakah dengan terbitnya, bisa memihak perempuan ataukah sebaliknya? karena para decision maker dari tingkat I dan II di Indonesia pada umumnya belum memiliki kepekaan terhadap KKG.

Berdasarkan uraian di atas dapat dirumuskan beberapa pokok pikiran sebagai berikut: Pertama, Indonesia adalah negara hukum yang mengakui kesetaraan laki-laki dan perempuan, baik dalam konstitusi maupun instrumen peraturan dan perundangundangan lain, terutama setelah ikut meratifikasi instrumen Internasional Hak Asasi Manusia (ICCPR dan ICESCR); Kedua, gerakan kaum perempuan di Indonesia tampaknya sudah ada bersamaan dengan gerakan kebangkitan kebangsaan dan perjuangan membela kemerdekaan. Bahkan kondisi perempuan pada saat itu telah memiliki kesadaran untuk berpolitik baik pada tingkat lokal dan regional maupun Internasional; Ketiga, partisipasi perempuan dalam proses pengambilan keputusan dan kebijakan publik telah diatur dalam Instruksi Presi- 
den Nomor 9 Tahun 2000 tentang Pengarus Utamaan Gender atau Meanstreming Gender, yang mana seluruh aparat, departemen, non-departemen, angkatan, dan NGO hendaknya mampu melaksanakan kebijakan tersebut.

\section{Kedudukan Hakim Perempuan dalam Sistem Hukum Islam}

Perempuan dalam pandangan hukum Yunani Kuno tampaknya dipandang hanya sebatas sebagai "pembantu rumah tangga" dengan tugas tunggal melahirkan anak. Kesucian mereka sedemikan terperosok lebih rendah dari hewan dan bahkan disejajarkan dengan najis dan perbuatan syetan, ketika tidak lagi dibutuhkan kaum laki-laki. Situasi seperti ini dialami hampir oleh semua perempuan, termasuk masyarakat Arab pra-Islam, terutama ketika Islam belum datang membawa misinya.

Perempuan pra Islam dianggap sebagai aib, yang mana masyarakat jahiliyah akan mengubur hidup-hidup anak perempuan. Hal ini dijelaskan dalam QS. al-Nahl ayat 58-59 yang berbunyi:

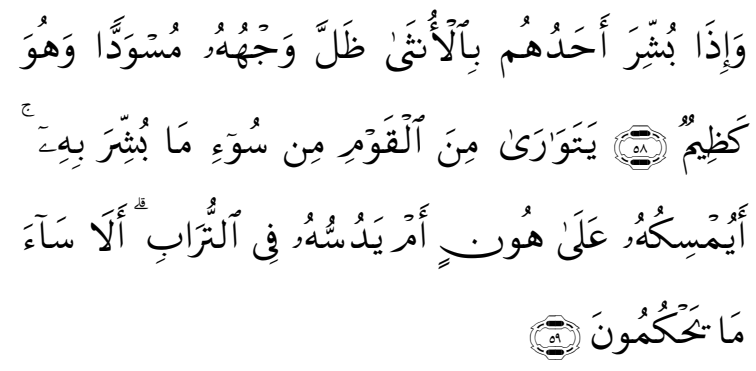

Dan apabila seseorang dari mereka diberi kabar dengan (kelahiran) anak perempuan, hitamlah (merah padamlah) mukanya, dan dia sangat marah. la menyembunyikan dirinya dari orang banyak, disebabkan buruknya berita yang disampaikan kepadanya. apakah dia akan memeliharanya dengan menanggung kehinaan ataukah akan menguburkannya ke dalam tanah (hidup-hidup)? Ketahuilah, alangkah buruknya apa yang mereka tetapkan itu.

Islam dengan seperangkat nilai yang dibawanya mencoba melakukan sebuah proses "revolusi" terhadap pandangan manusia tentang perempuan di dunia Arab. Secara perlahan tapi pasti, syariat Islam mulai mengangkat kaum perempuan dari kubangan diskriminatif yang berkepanjangan di masyarakat Arab. Rasulullah SAW telah memulai suatu tradisi baru dalam memandang perempuan. la melakukan dekonstruksi terhadap cara pandang masyarakat Arab yang memandang bahwa perempuan sebagai aib menjadi perempuan sama dengan laki-laki. Sejarah telah menunjukkan bahwa kedudukan perempuan pada masa Nabi Muhammad SAW bukan hanya dianggap sebagai isteri, pendamping, serta pelengkap laki-laki saja, akan tetapi lebih dipandang sebagai anak manusia yang memiliki kedudukan setara dalam hak dan kewajiban dengan manusia lainnya di hadapan Tuhan. Rasulullah SAW dalam sebuah haditsnya menegaskan kedudukan perempuan setara dengan laki-laki. Bahkan ia menegaskan bahwa kaum perempuan merupakan saudara bagi kaum laki-laki. ${ }^{20}$

Salah satu misi pokok Islam yang paling dominan adalah menjunjung tinggi harkat dan martabat perempuan. Dalam risalah Islam, hal ini banyak dijelaskan dalam al-Quran dan hadits Nabi sebagai sumber pokok hukum Islam. Pada kedua sumber pokok hukum Islam tersebut banyak dijelaskan bahwa perempuan memiliki hak yang sama dengan kaum laki-laki. Keduanya memiliki hak dan kewajiban yang seimbang, baik dalam status sipritual dan moral maupun dalam hak-hak ekonomis dan hak-hak legal (hukum). Hal ini tampaknya merupakan keistimewaan jika dibandingkan dengan ajaran agama lainnya. ${ }^{21}$

Berkenaan dengan hal tersebut di atas, Muhammad al-Gazâlî menegaskan bahwa:

Kalau kita mengembalikan pandangan ke masa sebelum seribu tahun, maka kita akan menemukan perempuan menikmati keistimewaan dalam bidang materi dan sosial yang tidak dikenal oleh perempuan-perempuan Barat dewasa ini,

20 Abû 'Îsâ Muhammad ibn 'Îsâ al-Tirmidzî, Jâmi` al-Tirmidzî, (Beirut: Dâr al-Ihyâ' al-Turats al-'Arabî. t.th.), juz 1, hlm. 190, Abî Dâwud Sulaymân ibn al-Asy'ats alSijistânî al-Azdî, Sunan Abî Dâwud (Beirut: Dâr al-Fikr. t.th.), juz 1, hlm. 61, dan Ahmad bin Hanbal, Musnad alImâm Ahmad bin Hanbal (Beirut: Dâr al-Fikr. t.th.), juz VI, hlm. 256.

${ }^{21}$ As‘ad al-Sahmarânî, al-Mar'ah fî al-Tarîkh wa al-Syar'iyyah (Beirut: Dâr al-Nafs. 1989), hlm. 127-128. 
asal saja kebebasan dalam berpakaian serta pergaulan tidak dijadikan perbandingan. ${ }^{22}$

Senada dengan pendapat di atas, Mahmud Syalthut juga menegaskan sebagai berikut:

Tabiat kemanusiaan antara laki-laki dan perempuan hampir dapat dikatakan sama. Allah telah menganugerahkan kepada perempuan sebagaimana menganugerahkan kepada laki-laki. Kepada mereka berdua dianugerahkan Tuhan potensi dan kemampuan yang cukup untuk memikul tanggung jawab dan menjadikan kedua jenis kelamin ini dapat melaksanakan aktivitas-aktivitas yang bersifat umum maupun khusus. Karena itu, hukum-hukum syariat-pun meletakkan keduanya dalam satu kerangka, yang ini (laki-laki) menjual dan membeli, mengawinkan dan kawin, melanggar dan dihukum, menuntut dan menyaksikan, dan yang itu (perempuan) juga demikian, dapat menjual dan membeli, mengawinkan dan kawin, melanggar dan dihukum, serta menuntut dan menyaksikan. ${ }^{23}$

Kedudukan perempuan dalam hukum Islam tampaknya sudah mengalami pencerahan yang cukup signifikan, hanya saja jika kemudian terjadi polemik para ulama dalam kapasitas perempuan sebagai hakim, tidak lepas dari kondisi sosial para ulama yang memandangnya saat itu. Kondisi sosial, budaya, dan struktur masyarakat tertentu diduga kuat mempunyai andil cukup besar terhadap pemikiran ulama dalam memandang kedudukan perempuan sebagai Hakim. Di samping itu, persoalan peradilan masih dianggap sesuatu yang riskan jika harus diserahkan pada perempuan. Itulah sebabnya mengapa kalangan ulama fikih telah melakukan usaha maksimal untuk membuat kualifikasi formal bagi seorang hakim.

22 Muhammad al-Gazâlî, al-Islâm al-Thâqah. hlm. 138.

23 Mahmoud Syalthout, Min Tawjihat al-Islâm. hlm. 193.
Kemudian penulis berpendapat bahwa sekurang-kurangnya ada tiga kelompok ulama yang menyatakan bahwa pendapat hukumnya berkaitan dengan hal tersebut, yaitu:

\section{Perempuan Tidak Sah Menjadi Hakim Secara Mutlak}

Perempuan dianggap tidak sah menjadi hakim secara mutlak dikemukakan oleh mayoritas ulama dari kalangan Mazhab Mâlikiyyah, Syafi'iyyah, Hanabilah, dan sebagian dari kalangan Mazhab Hanafiyyah. Mereka mensyaratkan jenis kelamin laki-laki sebagai keabsahan menjadi seorang hakim. ${ }^{24}$ Hakim 'lyadl dalam kitabnya misalnya menentukan syarat laki-laki sebagai hakim ${ }^{25}$, begitu juga dengan al-Mâwardî dari kalangan Syafi'iyyah memasukkan laki-laki sebagai syarat menjadi hakim. Lebih lanjut al-Mâwardî mensyaratkan calon hakim di peradilan umum, yaitu mereka harus memenuhi kriteria memiliki status sosial yang tinggi, memiliki ketegasan sikap, mempunyai kewibawaan dan kharisma, mempunyai kehormatan diri ('iffah), tidak korup (thama'), dan memiliki sifat wa$\mathrm{ra}^{\prime} .{ }^{26}$ Perempuan tidak sah menjadi hakim untuk segala urusan, meskipun mereka dapat bersaksi untuk masalah tersebut. ${ }^{27}$

Ulama lain yang menyinggung persyaratan laki-laki adalah Ibnu Rusyd dalam kitab Bidâyat al-Mujtahid dan Wahbah al-Zuhaili dalam kitabnya al-Fiqh al-Islâm wa Adillatuh. Keduanya menyimpulkan adanya perbedaan ulama tentang persyaratan seorang hakim. Persyaratan-persyaratan tersebut ada yang disepakati oleh kalangan fuqahâ' dan ada

24 Wahbah Zuhaylî, al-Figh al-Islâm wa Adillatuh (Beirut: Dâr al-Fikr al-Mu'âshir. 2004), juz VIII, hlm. 5937, juga Sayyid Sabiq, Fiqh al-Sunnah (Beirut: Dâr alFikr. 1983), juz III, hlm. 315.

25 Khayr al-Dîn al-Zarkalî, al-A'lâm (Beirut: Dâr alFikr .2005), jilid V, cet. ke-16, hlm. 99.

26 Abû al-Hassan 'Alî ibn Muhammad ibn Habîb al-Bashrî al-Mâwardî, Al-Ahkâm al-Shulthâniyyah (Beirut: Dâr al-Fikr. t.th.), hlm. 77.

${ }_{27}$ Mâlik bin Anas, al-Mudawwanah al-Kubrâ (Beirut: Dâr al-Fikr. t.th.), hlm. 83. Muhammad bin Ahmad bin Muhammad bin Ahmad bin Rusyd alQurthubî, Bidâyah al-Mujtahid wa Nihâyat al-Muqtashid (Mesir: Maktabah al-Kulliyat al-Azhariyyah. 1986), hlm. 83. Abû al-Hassan 'Ali ibn Muhammad ibn Habîb alBashrî al-Mâwardî, Adab al-Qâdli (Beirut: Dâr al-Fikr. t.th.), juz I, hlm. 627. 
pula yang diperselisihkan di antara mereka. ${ }^{28}$ Di antara syarat-syarat hakim yang disepakati adalah berakal, dewasa, merdeka, muslim, mendengar, melihat, dan berfikir (nâthiq). Sedangkan persyaratan yang diperselisihkan adalah bersikap adil, berjenis kelamin lakilaki, dan mampu berijtihad. ${ }^{29}$

Alasan penolakan terhadap perempuan menjadi hakim disebabkan perempuan memiliki kekurangan dan kelemahan. Perempuan memiliki kelemahan dari berbagai aspek; kurang kecerdasannya, kurang wawasan, kurang pergaulan dan mengalami keterbatasan dalam berinteraksi dengan lawan jenis. $^{30}$ Ulama menyimpulkan bahwa kurangnya akal perempuan ini menyebabkan kesaksian perempuan bernilai setengah dibanding persaksian laki-laki. ${ }^{31}$ Karena perempuan lemah akalnya, maka tidak bisa menduduki jabatan yudikatif, karena kedudukan ini menuntut kesempurnaan akal. Allah telah mengutamakan kaum laki-laki melebihi kaum perempuan dalam hal akal dan pendapat. ${ }^{32}$ Perempuan menurut petunjuk syara' hanya diberi tanggung jawab untuk menjaga harta suaminya. ${ }^{33}$

Perempuan tidak boleh menjadi hakim, karena perempuan memiliki kekurangan dan karena perkataan perempuan kadangkadang menjadi fitnah, serta wajah cantik sebagian perempuan terkadang menjadi fitnah.

\section{Perempuan dapat Menjadi Hakim untuk Perkara Perdata dan Tidak untuk Perkara Pidana (Qishash, Hudud, dan Ta'zîr)}

Pendapat ini dikemukakan oleh sebagian kalangan ulama dari Mazhab Hanafiyyah. Mazhab Hanafiyah berpendapat perempuan dapat menjadi saksi untuk perkara

28 Ibn Rusyd, Bidâyat al-Mujtahid. hlm. 449. Syayikh Muhammad al-Khâthib al- Syarbînî, Mugni alMuhtâj ila Ma'rifah Ma'âni al-Minhâj (Beirut: Dâr al-Fikr. t.th.), juz VI, hlm. 375.

${ }^{29}$ Wahbah Zuhaylî, al-Fiqh al-Islâm. hlm. 5936.

30 Ibid. hlm. 5937.

31 Salim Ali Bahnasawi, Wawasan Sistem Politik Islam (Jakarta: Pustaka Al-Kautsar. 1996), hlm. 293-294.

32 al-Mâwardî, Adab al-Qâdli. hlm. 627.

33 M. Syuhudi Ismail, Hadits Nabi yang Tekstual dan Kontekstual (Jakarta: Bulan Bintang. 1994), hlm. 65. perdata, karenanya dapat pula menjadi hakim dalam urusan muamalat (perdata), tidak pada kasus yang lain. ${ }^{34}$ Akan tetapi orang yang mengangkat perempuan menjadi hakim dalam masalah perdata, ia telah berdosa, meskipun si perempuan boleh menjadi hakim kasus perdata. Larangan perempuan menjadi hakim pidana dan qishash karena perempuan tidak bisa menjadi saksi untuk kasus pidana. Kapabilitas untuk menjadi seorang hakim tergantung kepada kapabilitas untuk menjadi saksi.

Pendapat lain mengatakan hukum perempuan menjadi hakim adalah makruh. Alasan kemakruhannya karena di dalam persidangan, hakim perempuan terpaksa harus bercakap-cakap dengan kaum laki-laki, padahal perempuan dianjurkan untuk selalu menutup diri (dari bergaul dan bercakap-cakap yang intens dengan laki-laki). Namun apabila dua pihak yang berperkara adalah perempuan semua, maka kemakruhan hakim perempuan menjadi hilang. ${ }^{35}$

Ibnu Hammâm, salah satu tokoh Mazhab Hanafiyyah, berpendapat kelaki-lakian tidak menjadi syarat untuk menjadi hakim kecuali dalam masalah hudud dan dima' (pidana). Perempuan dapat menjadi hakim kecuali dalam masalah pidana. ${ }^{36}$ Sedangkan Landasan pendapat kalangan Hanafiyyah ini didasarkan atas nash dan qiyas. Dalam surat al-Tawbah ayat 71 disebutkan kesetaraan laki-laki dan perempuan:
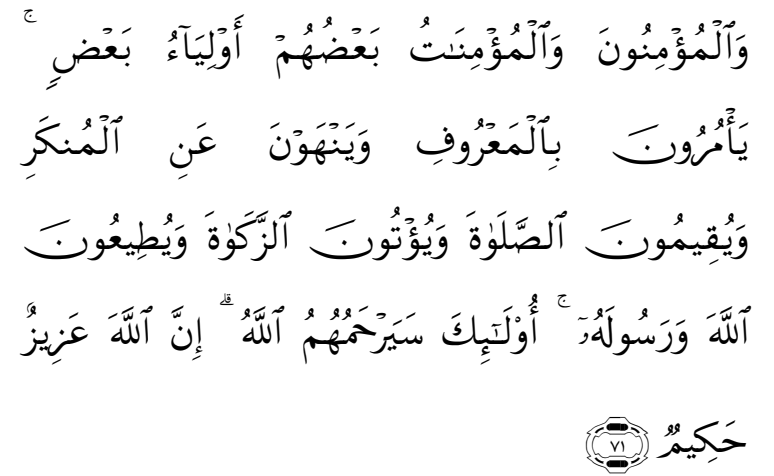

34 Wahbah Zuhaylî, al-Fiqh al-Islâm. hlm. 5937.

35 Syaykh As'ad Sa'îd al-Shâgirijî, al-Fikh al-Hanafî wa Adillatuh (Pakistan: Idarat al-Qur'an wa al-'Ulum alIslamiyah. $1421 \mathrm{H}$.), juz III, hlm. 10.

36 Ibnu Hammâm, Mu'în al-Hukkâm fîmâ Yataraddad Bayn al-Khashmayn min al-Ahkâm (Mesir: Maktabah Mushthafa al-Bab al-Halâbî wa Awladuh. 1973), juz. VII, hlm. 253. 
Dan orang-orang yang beriman, laki-laki dan perempuan, sebahagian mereka menjadi penolong bagi sebahagian yang lain. Mereka menyuruh yang ma'ruf, mencegah dari yang munkar, mendirikan shalat, menunaikan zakat dan mereka ta'at pada Allah dan Rasul-Nya. Mereka itu akan diberi rahmat oleh Allah; sesungguhnya Allah Maha Perkasa lagi Maha Bijaksana. (QS. al-Tawbah: 71)

Laki-laki dan perempuan memiliki peran dan tanggung jawab yang sama dalam kancah politik di masyarakat. Kekuasaan legislatif, eksekutif, dan yudikatif tampaknya merupakan arena untuk menegakkan 'amar $\mathrm{ma}^{\text {'- }}$ ruf nahyi munkar. Lembaga legislatif berjuang dengan berijtihad untuk membentuk undang-undang dan peraturan yang bermanfaat. Lembaga yudikatif berjuang dengan menyelesaikan sengketa setiap orang yang berperkara dengan seadil-adilnya. Lembaga eksekutif berjuang dengan menjalankan roda pemerintahan dengan sebaik-baiknya.

Berkenaan dengan hal tersebut, baik laki-laki maupun perempuan juga memiliki kewajiban yang sama untuk 'amar ma'ruf nahyi munkar, sehingga perempuan boleh menjadi hakim. Dalil qiyas yang digunakan adalah kaidah yang menyatakan bahwa: "Orang yang layak menjadi saksi, maka ia layak untuk menjadi hakim, karena kehakiman dibangun atas kesaksian." Dengan demikian, kelayakan menjadi hakim tergantung kelayakan menjadi saksi.

\section{Perempuan dapat Menjadi Hakim dalam Semua Perkara (Perdata dan Pidana)}

Pendapat ini dikemukakan oleh Ibnu Jarîr al-Thabarî, Ibnu Hazm, dan Muhammad bin Hasan. Ketiganya berpendapat bahwa perempuan dapat menangani semua kasus di pengadilan tatkala perannya sebagai hakim. Menurut Imâm al-Bajî, ${ }^{37}$ Setidaknya

37 Imâm al-Bâjî, al-Muntaqâ Syarh Muwaththa' alImâm Mâlik. juz. V, hlm. 182. Abû Muhammad 'Abdullah bin Ahmad bin Muhammad bin Qudâmah al-Maqdisy, al-Mugnî (Riyâd: Maktabah al-Riyad al-Haditsah. t.th.), juz. IX, hlm. 39. Abû Muhammad 'Alî bin Ahmad bin Sayd bin Hazm, al-Muhallâ (Beirut: Dâr al-Afaq alJadidah. 1988), juz. 9, hlm. 425. ada empat dalil yang dipergunakan oleh pendapat ketiga yang mengatakan sahnya perempuan menjadi hakim dalam semua perkara baik pidana maupun perdata. Dalil-dalil tersebut adalah sebagai berikut:

a) Ayat-ayat al-Quran dan hadits-hadits Nabi SAW menetapkan bahwa orang-orang muslim, laki-laki dan perempuan, sebagian mereka adalah pemimpin bagi sebagian yang lain. Dan menurut asalnya perkara adalah "persamaan" di antara kaum laki-laki dan perempuan, kecuali adanya dalil khusus yang menyebutkan pengecualian jenis kekuasaan tertentu yang tidak boleh diduduki oleh perempuan, yaitu kekuasaan imâmah 'uzhma. Sedangkan kekuasaan yang selain imâmah 'uzhma sangat terbuka lebar bagi kaum perempuan untuk mendudukinya. Di antara ayat yang menunjukkan persamaan kaum laki-laki dan perempuan dalam memimpin adalah ayat berikut:

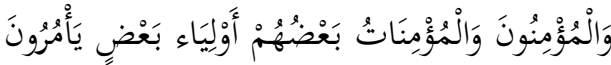

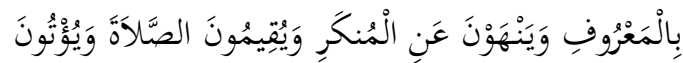

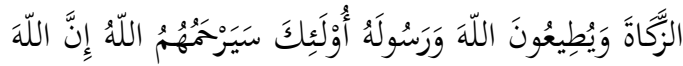

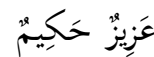

Dan orang-orang yang beriman, laki-laki dan perempuan, sebahagian mereka menjadi penolong bagi sebahagian yang lain. Mereka menyuruh yang ma'ruf, mencegah dari yang munkar, mendirikan shalat, menunaikan zakat dan mereka taat pada Allah dan Rasul-Nya. Mereka itu akan diberi rahmat oleh Allah; sesungguhnya Allah Maha Perkasa lagi Maha Bijaksana. (QS. al-Tawbah: 71)

b) Hadits yang diriwayatkan oleh Ibnu 'Umar, bahwa Rasulullah SAW telah bersabda: ( كلكم راع وكلكم مسؤل عن ر راعيته ) yang bermakna, "Setiap kalian adalah pemimpin. Dan setiap kalian akan dimintai pertanggungjawaban terhadap apa yang kalian pimpin." (HR. Muslîm)

Mengacu kepada penjelasan Rasulullah SAW di atas, disebutkan bahwa setiap orang adalah pemimpin, tanpa membedakan jenis kelaminnya. Hal ini menunjukkan bahwa kaum perempuan juga ber- 
hak menjadi pemimpin dan juga hakim sebagaimana halnya kaum laki-laki. Selain itu, konteks hadits tersebut menunjukkan adanya proses revolusi budaya, yaitu pergantian kepemimpinan yang sebelumnya dijabat laki-laki lalu pertama kali dijabat perempuan, yaitu Buwarân binti Syayrawayh bin Kisrâ bin Bawâriz..$^{38}$ la adalah Ratu Pertama di Persia, sementara kemampuannya sangat terbatas. Kegagalan Ratu Persia ini disebabkan karena ketidakmampuannya mengendalikan situasi keamanan di dalam negeri pada saat itu. Karena ketidakmampuannya itu, kemudian muncul pandangan bahwa perempuan dianggap tidak layak menjadi pemimpin.

Hadits tersebut juga diriwayatkan oleh Abû Bakrah pada saat terjadinya Perang Jamal antara 'Alî bin Abî Thalib dan Siti 'Aisyah, yakni Khalifah 'Alî bin Abî Thalib merebut Basrah setelah mengalahkan Siti 'Aisyah dalam perang tersebut. Abû Bakrah mengemukakan bahwa hadits tersebut muncul setelah berakhirnya antara 'Ali bin Abî Thalib dan Siti 'Aisyah (Perang Jamal).

Kalangan ahli takhrij hadits mempersoalkan keberadaan Abû Bakrah sebagai satusatunya sahabat yang meriwayatkan hadits tersebut. Misalnya, Fâthimah Marnîsî mempersoalkan keadilan Abû Bakrah karena beberapa alasan sebagai berikut:

1) Abû Bakrah semula adalah seorang budak yang kemudian dimerdekakan, karenanya ia sulit dilacak silsilahnya. Dalam tradisi kesukuan dan aristokrasi Arab, tanpa silsilah yang jelas maka secara sosial tidak diakui statusnya. Atas dasar itu pula, para penulis biografi berada dalam kondisi yang canggung dalam menghadapi Abû Bakrah ini. Bahkan Imâm Ahmad bin Hanbal mengakui bahwa silsilah para sahabat telah melewatkan begitu saja dan tidak menyelidikinya secara detail;

2) Abû Bakrah pernah menerima hukuman dera karena tuduhan zina (qadzaf)

38 Moh. Musta'in, Takhrij Hadits Kepemimpinan Wanita (Surakarta: Pustaka Cakra. 2001), hlm. 89-90. pada masa Khalifah 'Umar bin Khatab. Peristiwa ini terjadi pada waktu ia menjadi saksi atas kasus Mughirah bin Syu'bah yang dituduh melakukan zina. Oleh karena itu, Abû Bakrah harus ditolak sebagai sumber hadits karena telah memberikan suatu kesaksian palsu; dan

3) Alasan lain adalah konteks sosial-budaya, di mana Abû Bakrah meriwayatkan hadits tersebut ketika terjadi fitnah Perang Jamal. Meskipun saat itu Abû Bakrah bersifat netral, tetapi dalam kondisi tersebut ia terkesan menjustifikasi kekalahan Siti 'Aisyah. ${ }^{39}$

c) Qiyas, yaitu:

1) Menyamakan hukum bolehnya perempuan menjadi hakim sama dengan hukum kebolehan perempuan untuk menjadi mufti. Perempuan diperbolehkan menjadi mufti secara ijma'. Dihikayatkan dalam kitab tafsir, bahwa Ibnu Jarir mengatakan perempuan boleh menjadi hakim sebagaimana ia boleh menjadi mufti; ${ }^{40}$

2) Menyamakan hukum bolehnya perempuan menjadi hakim sama dengan hukum bolehnya perempuan menjadi auditor. Ibnu Hazm mendalilkan bolehnya perempuan menjadi hakim, dengan riwayat dari 'Umar bin Khattab bahwa beliau pernah mengangkat Syifâ', ${ }^{41}$ seorang perempuan dari kaum Quraisy untuk menjadi auditor pasar. Oleh karena itu, Ibnu Hazm beranggapan bahwa jika perempuan boleh menjadi auditor, berarti perempuan juga boleh menjadi hakim, karena kedudukan sebagai auditor atau hakim sama-sama merupakan jabatan yang memegang kekuasaan publik; dan

3) Penggunaan kesamaan illat baik dari wujud maupun sifat hukumnya (qiyas syumulî) bagi dalil qathî̀ dan zhanni di-

39 Ibid.

40 Ibnu Hazm, al-Mugnî. hlm. 39.

41 Nama lengkapnya al-Syifâ' binti 'Abdullah bin 'Abd al-Syams al-Qurâsyiyyah al-Adâwiyyah. Lihat Syihâb al-Dîn Ahmad bin 'Alî Muhammad bin Muhammad bin 'Alî al-Kanânî al-'Asqalânî, al-Ishâbah fî Tamyîz alShahâbah (Beirut: Dâr al-Kutûb al-'Arâbiyyah. t.th.), hlm. 333 . 
bolehkan untuk menyatakan bahwa perempuan boleh menjadi hakim dalam semua perkara.

d) Jenis kelamin laki-laki bukan merupakan hal yang penting sehingga keabsahan sebagai hakim tidak harus berjenis kelamin laki-laki.

Berdasarkan paparan perbedaan pendapat ulama di atas, penulis merumuskan pendapat ketiga yang membolehkan perempuan menjadi hakim secara mutlak adalah pendapat yang kuat. Ada beberapa alasan yang menjadi dasar keunggulan pendapat ketiga ini, yaitu:

a) Kuatnya dalil yang dikemukakan oleh kelompok pendukung pendapat ketiga serta kuatnya argumen mereka dalam menyanggah dalil pendapat pertama sebagaimana disebutkan di atas. Kekuatan dalil yang dimaksud adalah bahwa tidak ada satu keterangan ayat-ayat dalam al-Quran dan hadits Nabi Muhammad SAW yang secara tegas melarang perempuan sebagai hakim;

b) Tidak ada satupun dalil yang qath'î altsubût wa al-dilâlah yang menunjukkan wajibnya syarat bahwa hakim harus lakilaki. Dan perkara kehakiman adalah perkara muamalah sehingga berlaku kaedah al-ashl fil asyyâ' al-ibâhah illâ mâ dalla aldalîl 'alâ tahrîmih (asalnya perkara hukumnya mubah/boleh, kecuali jika ada dalil lain yang mengharamkannya). Oleh karena itu, kedudukan hakim perempuan masih berada dalam area kemubahan, seperti yang disebutkan dalam kaedah. Adapun kemubahan perempuan menjadi pemimpin hanya terbatas pada selain imâmah 'uzhma, sebab ada nash yang menunjukkan larangan perempuan menjadi pemimpin dalam imâmah 'uzhma; dan

c) Sistem peradilan yang dikenal pada zaman sekarang, adalah sistem peradilan yang terdiri dari tiga tingkatan, yaitu Pengadilan Tingkat Pertama, Pengadilan Tingkat Banding, dan Pengadilan Tingkat Kasasi. Kemudian, dalam setiap tingkat pengadilan tersebut, hakim yang bertugas memeriksa perkara bukan hakim tunggal, tetapi adalah hakim majelis yang terdiri dari tiga orang hakim. Sehingga keputusan yang akan diambil adalah kepu- tusan mayoritas, bukan keputusan seorang hakim perempuan. Apalagi sangat jarang terjadi dalam majelis hakim yang terdiri dari tiga orang hakim, ketiganya adalah perempuan. ${ }^{42}$ Oleh karena itu, larangan perempuan menjadi hakim di zaman sekarang tidak relevan lagi.

Mengacu kepada uraian di atas, penulis dapat merumuskan bahwa peluang besar bagi perempuan untuk menjadi hakim pada semua lembaga peradilan di Indonesia semakin terbuka ketika pemerintah mengeluarkan Instruksi Presiden Nomor 9 Tahun 2000 tentang Pengarus Utamaan Gender atau Meanstreming Gender, yang mana seluruh aparat, departemen, non-departemen, angkatan, dan NGO untuk melaksanakan kebijakan tersebut. Hal ini menjadi sinyal positif dan terbuka bahwa perempuan mendapatkan kedudukan hukum yang memadai dalam peraturan dan perundang-undangan di Indonesia.

\section{E. Peningkatan Kapasitas Hakim Perem- puan di Pengadilan Agama}

Dalam sistem peradilan, hakim memegang peranan yang sangat penting. la tidak hanya sebagai penegak hukum dan keadil$a^{4}{ }^{43}$ tetapi hakim juga sebagai pejabat negara yang mempunyai tugas mulia dalam rangka mewujudkan negara hukum dan selalu berupaya memberikan suatu kepastian hukum $^{44}$ dan juga kemanfaatan ${ }^{45}$ di tengah-

42 Meskipun dalam beberapa fakta yang pernah penulis alami terjadi majelis hakim seluruhnya perempuan.

43 Dalam menegakkan keadilan melalui putusan hakim dalam proses persidangan yang adil harus diupayakan sekuat tenaga dan pikiran, sekalipun tekanan terhadap proses peradilan dan ancaman terhadap hakim-hakim yang menangani perkara tersebut harus menjadi bayarannya. Kemudian peradilan memang kadang harus dibayar dengan pengorbanan yang demikian besar dari para pelaku peradilan, termasuk para hakim di Pengadilan. Whitney North Seymour Jr., Why Justice fails (New York: William Morrow \& Company. 1973), hlm. xiii. Di Indonesia, Ahmad Taufik, hakim Pengadilan Agama Sidoarjo wafat ketika sedang menjalankan tugas diruang sidang Pengadilan Agama Sidoarjo akibat diserang dengan senjata tajam oleh salah satu pihak pencari keadilan,pada tanggal 21 September 2005.

44 Penegakkan hukum yang sesuai dengan rasa keadilan masyarakat dengan tetap memperhatikan kepastian hukum pada setiap individu warga negara, 
tengah kehidupan sosial masyarakat melalui putusan hukumnya di pengadilan. Hal ini mengingat, dalam pandangan Jeremy Bentham, proses persidangan harus menghasilkan putusan yang akurat, karena ada korelasi antara proses persidangan dengan hasil persidangan dan nilai-nilai yang terkait dengan proses hukum. ${ }^{46}$ Oleh karenanya, keadilan, kepastian hukum, dan kemanfaatan, harus menjadi konsen hakim dalam memutuskan perkara. Mengingat ketidakadilan dapat terjadi, menurut John Rawls, ${ }^{47}$ karena kegagalan hakim untuk menegakkan peraturan yang tepat atau menginterpretasi peraturan secara tepat.

Menurut Rawls, prinsip paling mendasar dari keadilan adalah bahwa setiap orang memiliki hak yang sama dari posisi-posisi me-

merupakan ekspresi nilai-nilai demokratik dalam suatu negara demokratis. Karena adanya keterkaitan antara nilai penunjang demokrasi dan elemen negara hukum, maka sering dijadikan satu napas umuk menyebutkan bentuk ideal negara hukum yang melindungi hak-hak warga negara dalam satu istilah negara hukum yang demokratis. John Rawls, A Theory of Justice (Massachusetts: The Belknap Press of Harvard University Press Cambridge. 1971), hlm. 235.

45 Kemanfaatan (utilities) akan diperoleh melalui keberhasilan proses penegakan hukum dan sangat terkait dengan tercapainya rasa keadilan masyarakat sebagai elemen penting dalam sistem yang demokratis. Karenanya, John Rawls melihat pentingnya sistem hukum untuk melaksanakan prinsip kebebasan dan keadilan. Karena itu kehadiran sistem hukum merupakan suaru keharusan dalam suatu masyarakat. John Rawls, A Theory of Justice. hlm. 235.

46 Putusan hakim yang akurat, akan memperlihatkan digunakannya nilai-nilai sebagai dasar dari putusan tersebut. Karena itu, keluarnya putusan yang akurat juga terkait dengan dipakainya hukum pembuktian selama proses pemeriksaan perkara di pengadilan. Lahirnya putusan yang akurat juga berarti terfasilitasinya keadaan dalam proses peradilan. D.j. Colligan, Due Process. hlm. 10.

47 John Rawls (lahir pada tahun 1921) adalah filsuf dari Amerika Serikat yang terkenal pada abad ke20 di dalam bidang filsafat politik. Bukunya yang berjudul "Teori tentang Keadilan" (dalam bahasa Inggris A Theory of Justice) merupakan salah satu teks primer di dalam filsafat politik. Rawls belajar di Universitas Princeton, serta mengajar di Universitas Cornell dan Universitas Harvard. Lihat Freeman Samuel, "John Rawls" dalam In The Cambridge Dictionary of Philosophy. Robert Audi, ed. 774 (London: Cambridge University Press. 1999), hlm. 2. dan Ted Honderich, The Oxford Companion to Philosophy (New York: Oxford University Press. 1995), hlm. 745. reka yang wajar. Oleh karena itu, supaya keadilan dapat tercapai maka struktur konstitusi politik, ekonomi, dan peraturan mengenai hak milik haruslah sama bagi semua orang. Situasi seperti ini disebut "kabut ketidaktahuan" (veil of ignorance), di mana setiap orang harus mengesampingkan atributatribut yang membedakannya dengan orangorang lain, seperti kemampuan, kekayaan, posisi sosial, pandangan religius dan filosofis, maupun konsepsi tentang nilai. Untuk mengukuhkan situasi adil tersebut perlu ada jaminan terhadap sejumlah hak dasar yang berlaku bagi semua, seperti kebebasan berpendapat, kebebasan berpikir, kebebasan berserikat, kebebasan berpolitik, dan kebebasan di mata hukum. Dengan kata lain, hakikat keadilan menurut John Rawls adalah kondisi kebenaran ideal secara moral mengenai sesuatu hal, baik menyangkut benda atau orang. ${ }^{48}$ Menurut sebagian besar teori, keadilan memiliki tingkat kepentingan yang besar. Rawls menyatakan bahwa keadilan adalah kelebihan (virtue) pertama dari institusi sosial, sebagaimana halnya kebenaran pada sistem pemikiran. Tapi, menurut kebanyakan teori juga, keadilan belum lagi tercapai: "kita tidak hidup di dunia yang adil". 49 Kebanyakan orang percaya bahwa ketidakadilan harus dilawan dan dihukum, dan banyak gerakan sosial dan politis di seluruh dunia yang berjuang menegakkan keadilan. Ta$\mathrm{pi}$, dengan banyaknya jumlah dan variasi teori keadilan memberikan pemikiran bahwa tidak jelas apa yang dituntut dari keadilan dan realita ketidakadilan, karena definisi apakah keadilan itu sendiri tidak jelas. Keadilan intinya adalah meletakkan segala sesuatunya pada tempatnya. ${ }^{50}$

Untuk mengoptimalkan peran dan kedudukan hakim perempuan dalam menegakan hukum dan keadilan bagi masyarakat di Peradilan Agama, Mahkamah Agung Republik Indonesia terus mendorong peme-

\footnotetext{
48 John Rawls, A Theory of Justice (revised edn, Oxford: OUP. 1999), hlm. 3.

49 Thomas Nagel, The Problem of Global Justice: Philosophy and Public Affairs 33 (2005). hlm. 113-147.

50 Penulis mengutip teori keadilan sosial (the theory of justice) yang dikemukakan oleh John Rawls dari http://id.wikipedia.org/wiki/John_Rawls yang diakses tanggal 10 Juni 2010.
} 
nuhan kuota, meningkatkan pengetahuan, kompetensi, dan keahlian hakim perempuan. Misalnya, mengacu kepada syarat-syarat, kewenangan, dan tugas hakim yang diatur secara khusus dalam UU Nomor 4 Tahun 2004 tentang Kekuasaan Kehakiman menjadi dasar untuk merekrut hakim perempuan yang profesional. Dalam UU tersebut, secara substansi disebutkan bahwa hakim merupakan penegak hukum yang berwenang menyelesaikan perkara di pengadilan.

Untuk meningkatkan kompetensi dan keahlian hakim perempuan dalam penegakkan hukum di Peradilan Agama, Mahkamah Agung Republik Indonesia berupaya mendorong semua hakim perempuan untuk memiliki kemampuan yang maksimal dalam bidang ilmu hukum. Di antara upaya pembinaan yang dilakukan oleh Mahkamah Agung adalah:

1. Mendorong hakim-hakim perempuan di lingkungan Peradilan Agama untuk meningkatkan pengetahuan dan kompetensinya dengan cara melanjutkan studi baik pada jenjang Magister maupun Doktor di bidang ilmu hukum dan hukum Islam. Upaya ini dilakukan mengingat dari segi jumlah, populasi hakim perempuan di Peradilan Agama masih belum memenuhi kuota 30\% daripada jumlah hakim laki-laki. Sedangkan porsi hakim perempuan di lingkungan Peradilan Umum (Pengadilan Negeri) telah terpenuhi kuota $30 \%$, seperti halnya juga pemenuhan kuota 30\% keterwakilan perempuan di parlemen;

2. Mendorong hakim-hakim perempuan di lingkungan Peradilan Agama untuk mengikuti berbagai kegiatan pendidikan dan pelatihan, kursus-kursus bidang yudisial, workshop-workshop dan seminar-seminar, baik dalam skala lokal, nasional maupun Internasional, dalam rangka meningkatkan wawasan, pengetahuan dan keahlian di bidang hukum; dan

3. Mendorong hakim-hakim perempuan di lingkungan Peradilan Agama untuk diikutsertakan dalam program studi banding ke berbagai lembaga peradilan di seluruh wilayah Indonesia dan negara tetangga seperti Malaysia, Singapore, dan Brunei Darussalam mengenai peran hakim pe- rempuan dalam proses penegakan hukum di lembaga peradilan.

Selain melalui ketiga kebijakan di atas, upaya peningkatan kemampuan hakim perempuan dalam menegakan hukum dan keadilan di Peradilan Agama, juga diarahkan bukan hanya sebagai pemutus perkara, tetapi juga diarahkan untuk menjadi hakim mediator. Pembinaan yang dilakukan oleh Mahkamah Agung Republik Indonesia yang tertuang dalam Peraturan Mahkamah Agung Republik Indonesia Nomor 1 Tahun 2008 tentang Prosedur Mediasi di Pengadilan, antara lain:

1. Meningkatkan kemampuan hakim perempuan di bidang hukum dalam rangka membangun kepercayaan para pihak. Kemampuan ini merupakan sikap yang harus ditunjukan oleh hakim mediator kepada para pihak bahwa ia tidak memiliki kepentingan apapun terhadap penyelesaian sengketa. la semata-mata ingin menunjukkan keprihatinan bahwa sengketa yang tidak diselesaikan akan membawa dampak negatif, tidak hanya kepada individu tetapi juga kepada masyarakat. Hakim mediator hanya membantu para pihak untuk mengakhiri persengketaan, mengingat setiap manusia secara fitrah ingin bebas dari konflik dan persengketaan. Pada intinya, hakim mediator tidak memiliki kepentingan apapun kecuali kepentingan selesainya sengeketa yang membahagiakan kedua pihak. Oleh karena itu tidak layak bagi seorang hakim mediator jika dalam melaksanakan tugasnya memiliki kepentingan ekonomis terhadap permasalahan yang sedang menjadi sengketa;

2. Meningkatkan kemampuan hakim perempuan dalam menunjukkan sifat empati. Rasa empati ditunjukkan oleh seorang hakim mediator perempuan adalah dengan berusaha secara sungguh-sungguh untuk mencari jalan keluar agar para pihak dapat menyelesaikan sengketa yang dihadapinya. Hakim Mediator sedapat mungkin meyakinkan dan memastikan bahwa setiap sengketa yang dihadapi akan dapat dicarikan jalan pemecahannya jika para pihak menginginkannya. Seorang hakim mediator bukanlah seseorang yang dapat menentukan putusan 
sendiri mengenai siapa yang salah dan siapa yang benar. la hanya menengahi, mendorong dan membantu para pihak mencari penyelesaian yang dihadapi. la bersama para pihak menelusuri akar masalah sengketa yang timbul dan meminta serta menawarkan para pihak memikirkan alternatif pemecahannya;

3. Hakim perempuan didorong untuk tidak menghakimi dan memberikan reaksi positif maupun negatif terhadap sejumlah pernyataan yang disampaikan para pihak dalam proses mediasi, walaupun ia sendiri tidak setuju dengan pernyataan tersebut. Hakim mediator tidak boleh membantah secara langsung atau menyatakan bahwa pernyataan tersebut tidak tepat, tetapi ia hendaknya memberikan suatu penghargaan terhadap ide dan pernyataan apapun dari para pihak. Hakim mediator juga hendaknya menunjukkan sikap positif semacam ini agar para pihak nyaman dalam proses penegakan hukum di pengadilan;

4. Meningkatkan kemampuan hakim perempuan dalam berkomunikasi yang baik, jelas, dan teratur serta mudah dipahami para pihak karena menggunakan bahasa yang sederhana. Kalilmat yang digunakan hakim mediator bukanlah kalimat yang menimbulkan ambiguitas dan membuka peluang salah tafsir dari kedua belah pihak; dan

5. Meningkatkan kemampuan hakim perempuan dalam menjalin hubungan antar personal. Keahlian semacam ini diperlukan bagi seorang hakim mediator, biasanya hal tersebut dapat ditempuh dari pengalamannya menangani kasus-kasus di pengadilan atau hasil dari pergaulan sosial.

Pada gilirannya, penulis dapat merumuskan sebagai berikut: Pertama, kebijakan pembinaan terhadap hakim perempuan yang dilakukan oleh Mahkamah Agung tampaknya buhan hanya diarahkan untuk pengembangan kualitas sumber daya marusia, tetapi juga peningkatan pengetahuan dan keahlian hakim perempuan dalam proses penegakan hukum Islam di Peradilan Agama; Kedua, keberadaan hakim perempuan dalam proses penegakan hukum Islam di Peradilan Agama hendaknya ditujukan untuk mencapai tujuan primer (maqâshid al-dlarûriyyah), tetapi juga se- baiknya dilakukan oleh setiap hakim di lembaga peradilan lainnya untuk tujuan kemaslahatan, kepastian hukum, dan tegaknya hukum syari'ah; dan Ketiga, praktik penegakan hukum di Peradilan Agama oleh hakim mediator perempuan hendaknya tetap berpedoman kepada prinsip-prinsip, asas-asas, dan tujuan hukum Islam (maqâshid al-syarî́ah).

\section{F. Penutup}

Hakim perempuan hendaknya memberikan pencitraan yang baik sebagai hakim tauladan, baik kepada para pihak maupun kepada aparatur penegak hukum lainnya, selama ia menyelesaikan perkara di dalam lingkup peradilan. Pencitraan hakim perempuan sebagai aparatur penegak hukum, sangat terikat dengan kode etik dan sumpah profesinya. la tidak dibenarkan melakukan tindakan yang menyalahi hukum dan/atau membawa para pihak kepada pelanggaran hukum. Bahkan hakim perempuan diharuskan untuk menghormati hukum dan aparatur penegak hukum lainnya, serta yang paling penting adalah mematuhi hukum itu sendiri.

Hakim perempuan hendaknya memberikan pencitraan yang baik sebagai hakim tauladan, baik kepada para pihak maupun kepada aparatur penegak hukum lainnya, selama ia menyelesaikan perkara di dalam lingkup peradilan. Pencitraan hakim perempuan sebagai aparatur penegak hukum, sangat terikat dengan kode etik dan sumpah profesinya. la tidak dibenarkan melakukan tindakan yang menyalahi hukum dan/atau membawa para pihak kepada pelanggaran hukum. Bahkan hakim perempuan diharuskan untuk menghormati hukum dan aparatur penegak hukum lainnya, serta yang paling penting adalah mematuhi hukum itu sendiri.

\section{Daftar Pustaka}

'Abduh, Muhammad. t.th. Tafsîr al-Manâr. Kairo: Dâr al-Maktab al-Misriyyah.

'Abdullah, Muhammad Hussayn. t.th. alWâdlih fî Ushûl al-Fiqh. Beirut: Dâr alFikr.

'Asqalânî, Syihâb al-Dîn Ahmad bin 'Alî Muhammad bin Muhammad bin 'Alî alKanânî al-. t.th. al-Ishâbah fî Tamyîz al- 
Shahâbah. Beirut: Dâr al-Kutûb al'Arâbiyyah.

Adams, Wahiduddin dalam disertasinya yang berjudul "Pola Penyerapan Fatwa Majelis Ulama Indonesia MUI dalam Peraturan Perundang-undangan 1975 1997", menjelaskan adanya sumbangan hukum Islam terhadap hukum positif.

Anas, Mâlik bin. t.th. al-Mudawwanah alKubrâ. Beirut: Dâr al-Fikr.

Azdî, Abî Dâwud Sulaymân ibn al-Asy'ats alSijistânî al-. t.th. Sunan Abî Dâwud. Beirut: Dâr al-Fikr.

Gazâlî, Muhammad al-. 1964. al-Islâm alThâqah al-Mu'aththalah. Kairo: Dâr alKutûb al-Haditsah.

Hammâm, Ibnu. 1973. Mu'în al-Hukkâm fîmâ Yataraddad Bayn al-Khashmayn min alAhkâm. Mesir: Maktabah Mushthafa alBab al-Halâbî wa Awladuh.

Hanbal, Ahmad bin. t.th. Musnad al-Imâm Ahmad bin Hanbal. Beirut: Dâr al-Fikr.

Hazm, Abû Muhammad 'Alî bin Ahmad bin Sayd bin. 1988. al-Muhallâ. Beirut: Dâr alAfaq al-Jadidah.

Honderich, Ted. 1995. The Oxford Companion to Philosophy. New York: Oxford University Press.

Ismail, M. Syuhudi. 1994. Hadits Nabi yang Tekstual dan Kontekstual. Jakarta: Bulan Bintang.

Kusuma, M. Indradi dan Wahyu Effendi. 2002. Kewarganegaraan Indonesia: Catatan Kritis Atas Hak Asasi Manusia dan Institusionalisasi Diskriminasi Warga Negara. Jakarta: FKKB dan GANDI.

Maqdisy, Abû Muhammad 'Abdullah bin Ahmad bin Muhammad bin Qudâmah al.t.th. al-Mugnî. Riyâd: Maktabah al-Riyad al-Haditsah.

Mâwardî, Abû al-Hassan 'Ali ibn Muhammad ibn Habîb al-Bashrî al-. t.th. Adab alQâdli. Beirut: Dâr al-Fikr.

$$
\text { . t.th. Al-Ahkâm al- }
$$

Shulthâniyyah. Beirut: Dâr al-Fikr.

Muhammad, Hussein. 2001. Fiqh Perempuan. Yogyakarta: LkiS.

Konsepsi Fiqih tentang Perempuan, dalam Syafiq Hasyim (ed.), Kepemimpinan Perempuan dalam Islam. Jakarta: P3M.
Musta'in, Moh. 2001. Takhrij Hadits Kepemimpinan Wanita. Surakarta: Pustaka Cakra.

Nabhânî, Taqiy al-Dîn al-. t.th. Muqaddimah al-Dustûr. Beirut: Dâr al-Fikr.

Qurthubî, Muhammad bin Ahmad bin Muhammad bin Ahmad bin Rusyd al-. 1986. Bidâyah al-Mujtahid wa Nihâyat alMuqtashid. Mesir: Maktabah al-Kulliyat al-Azhariyyah.

Rawls, John. 1971. A Theory of Justice. Massachusetts: The Belknap Press of Harvard University Press Cambridge.

Sabiq, Sayyid. 1983. Fiqh al-Sunnah. Beirut: Dâr al-Fikr.

Sahmarânî, As'ad al-. 1989. al-Mar'ah fî alTarîkh wa al-Syar'iyyah. Beirut: Dâr alNafs.

Shâgirijî, Syaykh As'ad Sa'îd al-. 1421 H. al-Fikh

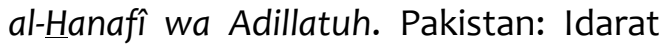
al-Qur'an wa al-'Ulum al-Islamiyah.

Shan'ânî, al-. t.th. Subul al-Salâm. Bandung: Maktabah Dahlan

Shihab, M. Quraish. 1996. Wawasan alQur'an. Bandung: Mizan.

Subhan, Zaitunah. 2004. Perempuan dan Politik dalam Islam. Yogyakarta: Pustaka Pesantren \& El-Kahfi. . 2008. Menggagas Fiqh Pemberdayaan Perempuan. Jakarta; elKahfi.

Suryanegara, Ahmad Mansur. 1999. Amerika Menolak Presiden Perempuan. Jakarta: Darul Falah.

Syalthut, Mahmud. 1959. Min Tawjihat alIslâm. Kairo: al-Idarat al-'Ammat alAzhar.

Syarbînî, Syayikh Muhammad al-Khâthib al-. t.th. Mugni al-Muhtâj ila Ma'rifah Ma'âni al-Minhâj. Beirut: Dâr al-Fikr.

Syawkânî, Muhammad bin 'Alî al-. t.th. Nayl al-Authâr. Beirut: Dâr al-Fikr.

Tirmidzî, Abû 'Îsâ Muhammad ibn 'Îsâ al-. t.th. Jâmi' al-Tirmidzî. Beirut: Dâr al-Ihyâ' al-Turats al-'Arabî.

Zarkalî, Khayr al-Dîn al-. 2005. al-A'lâm. Beirut: Dâr al-Fikr.

Zayd, Nasr Hamid Abû. 2000. Human Rights in Islam dalam Human Rights Quarterly. The Hague: Kluwer Law Unversity Press.

Zuhaylî, Wahbah. 2004. al-Fiqh al-Islâm wa Adillatuh. Beirut: Dâr al-Fikr al-Mu'âshir. 